\title{
Solvent Dosage Form Category
}

National Cancer Institute

\section{Source}

National Cancer Institute. Solvent Dosage Form Category. NCI Thesaurus. Code

C148549.

A type of liquid pharmaceutical dose form consisting of a vehicle that contains no active ing redient itself, and is used to dissolve, disperse or dilute another product. 